\title{
The effect of fibrin clots and clot-bound thrombin on the development of platelet procoagulant activity
}

Citation for published version (APA):

Kumar, R., Beguin, S., \& Hemker, H. C. (1995). The effect of fibrin clots and clot-bound thrombin on the development of platelet procoagulant activity. Thrombosis and Haemostasis, 74(3), 962-968.

https://doi.org/10.1055/s-0038-1649856

Document status and date:

Published: 01/01/1995

DOI:

10.1055/s-0038-1649856

Document Version:

Publisher's PDF, also known as Version of record

\section{Please check the document version of this publication:}

- A submitted manuscript is the version of the article upon submission and before peer-review. There can be important differences between the submitted version and the official published version of record.

People interested in the research are advised to contact the author for the final version of the publication, or visit the DOI to the publisher's website.

- The final author version and the galley proof are versions of the publication after peer review.

- The final published version features the final layout of the paper including the volume, issue and page numbers.

Link to publication

\footnotetext{
General rights rights.

- You may freely distribute the URL identifying the publication in the public portal. please follow below link for the End User Agreement:

www.umlib.nl/taverne-license

Take down policy

If you believe that this document breaches copyright please contact us at:

repository@maastrichtuniversity.nl

providing details and we will investigate your claim.
}

Copyright and moral rights for the publications made accessible in the public portal are retained by the authors and/or other copyright owners and it is a condition of accessing publications that users recognise and abide by the legal requirements associated with these

- Users may download and print one copy of any publication from the public portal for the purpose of private study or research.

- You may not further distribute the material or use it for any profit-making activity or commercial gain

If the publication is distributed under the terms of Article $25 \mathrm{fa}$ of the Dutch Copyright Act, indicated by the "Taverne" license above, 


\title{
The Effect of Fibrin Clots and Clot-Bound Thrombin on the Development of Platelet Procoagulant Activity
}

\author{
Rachana Kumar, Suzette Béguin, H. Coenraad Hemker
}

From the Department of Biochemistry, Faculty of Medicine and Cardiovascular Research Institute, University of Limburg, Maastricht, The Netherlands

\section{Summary}

We tested different types of clot for their ability to provoke procoagulant activity in platelets: normal clots from platelet poor plasma (des AABB- or fibrin II clots), similar clots in which the adsorbed thrombin has been inhibited by hirudin, and clots obtained by the action of two snake venom enzymes that release only fibrinopeptide A (des AA- or fibrin I clots). Analogous clots from fibrinogen solutions were also tested.

In platelet rich plasma (PRP), where platelet coagulant phospho lipids (PCP) are rate limiting for thrombin generation, the addition of any type of clot enhances the generation of thrombin thus it induces the appearance of PCP. Clots containing active adsorbed thrombin are the most potent ones in this respect. Lactate dehydrogenase (LDH) levels do not increase in the course of the thrombin generation so the platelets are not damaged in the process. Non-centrifugable PCP could be demonstrated to appear during the process, so the production of procoagulant phospholipid microparticles must be part of the mechanism. Membrane transbilayer phosphatidyl serine movement (flip-flop) can not be demonstrated in PRP as the activated platelets are caught in the emerging clot.

In order to demonstrate flip-flop, we tried to investigate the influence of clots on washed platelets. However, contrary to platelets in a plasma milieu, isolated platelets are damaged by fibrin clots, especially in the presence of thrombin, as can be judged from the appearance of $\mathrm{LDH}$.

We conclude that, in PRP, clots induce the appearance of PCP from platelets by vesiculation, possibly accompanied by flip-flop and that thrombin accelerates the process but is not an absolute requirement.

\section{Introduction}

It is becoming increasingly evident that primary haemostasis through platelet activation and aggregation and secondary haemostasis through clotting are processes that amplify each other in all types of haemostatic and thrombotic events (see ref. 1 for a review). A powerful resonance loop establishes itself at a site of vessel injury because thrombin very effectively activates platelets and activated platelets accelerate thrombin generation by exposing a procoagulant phospholipid surface (2-4) and releasing platelet factor $V(5-7)$. Thus, the formation of thrombin and platelet activation are interdependent processes and it is not easy to dissociate the role of one from another.

Correspondence to: Dr. S. Béguin, Faculty of Medicine and Cardiovascular Research Institute, Department of Biochemistry, University of Limburg, P, O. Box 616, NL-6200 MD Maastricht, The Netherlands - FAX Number: $+3143670988$
In the process of clotting of fibrinogen by thrombin, a certain amount of thrombin is adsorbed on the fibrin (8-11). Clot-bound thrombin still exhibits catalytic activity since it has been reported to catalyze the release of FPA from fibrinogen (12-14), to hydrolyse chromogenic substrates (13) and to shorten the coagulation time of blood and plasma (14-16). The fibrin clot thus behaves as a reservoir of enzymaticallyactive thrombin, more significantly so as the inhibition characteristics of bound thrombin by plasma antithrombins have been demonstrated to be much different from fluid phase thrombin, notably that this thrombin is insensitive to antithrombin $(11,12,15)$. There also arises the question, whether the adsorbed thrombin still could function in the thrombin-mediated feedback reactions that are so typical for the coagulation mechanism. Recently we have reported $(17,18)$ that clot-bound thrombin could indeed further enhance thrombin formation by sustaining the activation of plasma cofactor proteins factor $V$ and VIII. We have also observed that in platelet rich plasma (PRP) clots significantly lower the lag phase prior to the burst of thrombin generation, indicating that platelets are activated by clots.

The present article investigates the influence of clots produced by thrombin and non-thrombin enzymes on the stimulation of platelets. It has been shown that the major platelet surface receptor GPIIb/IIIa $\left(\alpha_{\text {IIb }} \beta_{3}\right.$ integrin) is activated by a variety of extracellular matrices including fibrin (19) leading to highly adherent behaviour of the platelets. Clots may also induce the platelet release reaction (14). Because there are several forms of platelet activation that do not lead to the exposure of procoagulant surfaces (20), it remains to be seen how the procoagulant behaviour of the platelets is affected by clots and clot bound thrombin. To this end, in the work presented here, we have studied the effect of different types of clots on the generation of platelet prothrombin converting activity in platelet rich plasma and in suspensions of washed platelets and compared it with the effect of well known platelet activators such as $\mathrm{Ca}^{2+}$-ionophore $\mathrm{A} 23187$ or IIa and collagen, alone or in combination.

\section{Materials and Methods}

\section{Materials}

Fatty acid free bovine serum albumin (BSA), ovalbumin (grade V) and Calcium ionophore, A23187 were purchased from Sigma (St. Louis, MO). Horse tendon collagen (type I) was from Hormon Chemie (Munich, Germany). Chromogenic substrate used for thrombin was S2238: H-D-Phe-Pip-ArgpNA.2HCI. Purified fibrinogen was obtained from Kordia (Leiden, The Netherlands). Reptilase was supplied by Laboratories Stago (Asnières, France) and Agihal, a purified fraction of Agkistrodon halys halys snake venom, that splits fibrinopeptide A from fibrinogen was obtained from Prof. L. Yukelson (Tashkent, Uzbekistan). Recombinant hirudin (Knoll AG) was a kind gift of Dr. W. Homberger. 


\section{Plasma}

PRP for thrombin generation experiments was obtained by centrifugation at $250 \mathrm{~g}, 15^{\circ} \mathrm{C}, 10 \mathrm{~min}$ of freshly drawn citrated blood (1 volume trisodium citrate $0.13 \mathrm{M}$ to 9 volumes blood) of a healthy donor. The platelet count was adjusted to $3^{*} 10^{8} / \mathrm{ml}$ with homologous platelet poor plasma (PPP) obtained by double centrifugation of PRP at $1000 \mathrm{~g}, 15^{\circ} \mathrm{C}, 10 \mathrm{~min}$.

PRP for the measurement of generation of platelet procoagulant activity was obtained from blood taken 5:1 on ACD (183 mM glucose, $80 \mathrm{mM}$ trisodium citrate, $52 \mathrm{mM}$ Citric acid) centrifuged under the same conditions as described above. The platelet count in this case was adjusted to $1 * 10^{8} / \mathrm{ml}$.

\section{Platelet Preparations}

Six volumes of blood drawn from healthy donors by venipuncture was collected on one volume of an anticoagulant mixture consisting of $42 \mathrm{mM}$ EDTA, $42 \mathrm{mM}$ trisodium citrate, $25 \mathrm{mM} \mathrm{NaOH}$ (pH 6.6). The blood was centrifuged for $15 \mathrm{~min}$ at $250 \mathrm{~g}$. The platelet rich supernatant thus obtained was subsequently centrifuged for 5 minutes at $160 \mathrm{~g}$ to remove any remaining erythrocytes and leukocytes. The PRP was further centrifuged for $15 \mathrm{~min}$ at $500 \mathrm{~g}$ and the platelet pellet was resuspended in 19 volumes buffer ( $\mathrm{pH} 6.6$ ) consisting of $25 \mathrm{mM}$ HEPES, $136 \mathrm{mM} \mathrm{NaCl}, 2.68 \mathrm{mM} \mathrm{KCl}, 1.7 \mathrm{mM} \mathrm{MgCl}$, $25 \mathrm{mM}$ glucose, $0.5 \% \mathrm{BSA}$ and 1 volume anticoagulant mixture (see above). Platelets were thus washed twice centrifuging at $500 \mathrm{~g}$ for $15 \mathrm{~min}$ and were finally resuspended in 1 volume Hepes buffer ( $\mathrm{pH}$ 6.6) and 4 volumes of same Hepes buffer ( $\mathrm{pH} 7.5$ ). The platelet concentrations were determined using a Coulter counter. All the platelet handling was done at room temperature.

\section{Proteins}

Human prothrombin was purified according to Discipio et al. (21). Thrombin was purified from prothrombin after activation with factor Xa as described by Rosing et al. (22). The thrombin concentration was determined by active site titration according to Chase and Shaw (23). Bovine factor $\mathrm{Xa}$ was prepared from factor $\mathrm{X}_{2}$ using RVV-X according to method of Fujikawa et al. (24). Factor $\mathrm{Xa}$ concentrations were calculated after active site titration according to Smith (25). Bovine factor V was purified by the procedure described by Dählback (26) and Suzuki et al. (27) with minor modifications as explained in ref. 28. Factor Va was prepared by activation of factor $V$ with thrombin and concentrations of Va were determined kinetically as described by Lindhout et al. (29).

\section{Methods \\ Preparation of Clots}

Plasma clots: PPP ( $250 \mu \mathrm{l}$ for one clot) was coagulated by recalcification to a final concentration of $23 \mathrm{mM} \mathrm{CaCl}_{2}$ in a glass tube and incubated at $37^{\circ} \mathrm{C}$ for $1 / 2 \mathrm{~h}$. The clot was wound on a plastic spatula, dried and incubated in (human) serum for $10 \mathrm{~min}$. The clot was then extensively washed in $2 \mathrm{ml}$ of Buffer A that was changed three times in order to eliminate any soluble material trapped in the clot. That no unbound thrombin remained with the clot was checked by the absence of amidolytic activity in the last washing buffer on $\$ 2238$.

Purified fibrinogen clots were prepared from $250 \mu 1$ of $3 \mathrm{mg} / \mathrm{ml}$ fibrinogen solution in $150 \mathrm{mM} \mathrm{NaCl}$, by adding $\mathrm{CaCl}_{2}(23 \mathrm{mM})$ and $1 / 50$ volume of Reptilase or Agihal solution or, in some cases, $30 \mathrm{nM}$ Пla. Extensive washing of the clots was practised in all the cases. Non-crosslinked fibrin clots i. e. des AA fibrin obtained by the action of snake venoms that only release fibrinopeptide A have been referred to as fibrin I clots while des AABB fibrin clots (cross linked) are designated as fibrin II clots.

\section{Measurement of Thrombin Generation in PRP}

This was done as previously described (30). Briefly, $240 \mu$ of PRP was diluted with $60 \mu \mathrm{l}$ of Buffer A ( $50 \mathrm{mM}$ Tris $\mathrm{HCl}, 100 \mathrm{mM} \mathrm{NaCl}, 0.5 \%$ BSA:
$\mathrm{pH} 7.35$ ) and coagulation was triggered with $60 \mu \mathrm{l} \mathrm{CaCl}$ (Final concentration $16.7 \mathrm{mM}$ ). The clots were added to the reaction mixture $90 \mathrm{~s}$ after triggering coagulation. The reaction mixture was continuously stirred by a small spatula and $10 \mu \mathrm{I}$ subsamples were drawn at equally spaced intervals and diluted in prewarmed $\left(37^{\circ} \mathrm{C}\right.$ ) cuvettes containing $490 \mu \mathrm{l}$ of Buffer B (Buffer A with $20 \mathrm{mM}$ EDTA, pH 7.9) containing $200 \mu \mathrm{M}$ S2238. The reaction was stopped after $2 \mathrm{~min}$ by adding $300 \mu \mathrm{l}$ of $1 \mathrm{M}$ Citric acid. As soon as the reaction mixture coagulated, the clot was wound on the spatula and discarded. From the rate of change of optical density measured at $405 \mathrm{~nm}$, the amidolytic activity was calculated by comparing with a standard calibration curve made with active site - titrated human $\alpha$-thrombin.

\section{Measurement of Platelet Prothrombin Converting Activity}

In washed platelet suspensions: The reaction mixture consisted of $343 \mu 1$ of washed platelet suspension with platelet count $0.5^{*} 10^{8} / \mathrm{ml}$ to which $7 \mu \mathrm{l}$ of $100 \mathrm{mM} \mathrm{CaCl}$ was added. The mixture was magnetically stirred at $37^{\circ} \mathrm{C}$ at $350 \mathrm{rev} / \mathrm{min}$ with teflon coated stirring bars. A stirring assembly was used which allowed to stir 7 reaction mixtures simultaneously at $37^{\circ} \mathrm{C}$. After 3 min prewarming, platelet activation was initiated by adding a platelet stimulator. The generation of platelet prothrombin-converting activity was determined by transferring a $10 \mu \mathrm{l}$ sample from the platelet activation mixture to $240 \mu \mathrm{l}$ of an assay mixture containing $3 \mathrm{nM}$ factor $\mathrm{Va}, 5 \mathrm{nM}$ factor $\mathrm{Xa}$ and $1 \mu \mathrm{M}$ prothrombin in $25 \mathrm{mM}$ Hepes (pH 7.7), $175 \mathrm{mM} \mathrm{NaCl}, 5 \mathrm{mg} \mathrm{BSA} / \mathrm{ml}, 2 \mathrm{mM} \mathrm{CaCl}_{2}$. A reference prothrombinase blank was measured by transferring a $10 \mu \mathrm{l}$ Hepes buffer $\mathrm{pH} 6.6$ aliquot to the prothrombinase mixture instead of the platelet activation mixture.

The formation of thrombin was stopped after 1 min by transferring $10 \mu \mathrm{l}$ aliquots to cuvettes (at $37^{\circ} \mathrm{C}$ ) with $990 \mu$ l buffer ( $50 \mathrm{mM}$ Tris, $175 \mathrm{mM} \mathrm{NaCl}$, $0.5 \mathrm{mg} / \mathrm{ml}$ ovalbumin, $20 \mathrm{mM}$ EDTA; $\mathrm{pH} 7.9$ ) containing $335 \mu \mathrm{M}$ S2238. From the absorbancy change recorded at $405 \mathrm{~nm}$, the amount of thrombin formed is calculated via a calibration curve made with known amounts of thrombin. The time course of generation of platelet prothrombin - converting activity was then determined by samples taken from the platelet activation mixture at various time intervals. Controls with non-stimulated platelets were always run in parallel. Finally, the amount of thrombin formed in the prothrombinase blank was subtracted from all the readings.

In PRP: $100 \mu \mathrm{l}$ of PRP, 1:6.7 diluted in Tris buffer A (see above) was incubated for 5 min with or without clots. $50 \mu \mathrm{l}$ subsample from PRP was then transferred to $100 \mu \mathrm{l}$ of an assay mixture containing $0.45 \mathrm{nM}$ factor $\mathrm{Xa}$, $10.5 \mathrm{nM}$ factor $\mathrm{Va}, 3 \mu \mathrm{M}$ Prothrombin and $12 \mathrm{mM} \mathrm{Ca}^{2+}$ in Tris buffer A. At $4 \mathrm{~min}, 10 \mu \mathrm{l}$ of subsample was taken to the cuvette containing $465 \mu \mathrm{l}$ of Tris buffer B (see above). The amount of thrombin formed was calculated from the absorbance change measurement at $405 \mathrm{~nm}$ after the addition of $25 \mu 1$ of $\mathrm{S} 2238$ (4 $\mathrm{mM})$.

\section{Release of Platelet Lactate Dehydrogenase (LDH)}

Samples were assayed for the release of platelet LDH by using a commercially available kit (Boehringer, Mannheim). $200 \mu \mathrm{l} \mathrm{PRP}$ or the activated platelet suspension was centrifuged at $9000 \mathrm{~g}$ for $3 \mathrm{~min}$ in an Eppendorf centrifuge. $5 \mu \mathrm{l}$ of the supernatant was added to a cuvette with $125 \mu \mathrm{l}$ of a buffer containing $51.7 \mathrm{mM}$ Phosphate buffer (pH 7.5), $0.19 \mathrm{mM} \mathrm{NADH}$ and $0.6 \mathrm{mM}$ Pyruvate. The activity of LDH was calculated from the absorbancy change at $334 \mathrm{~nm}$. The total LDH content of the platelets was determined in a platelet suspension that was sonicated for $1 \mathrm{~min}$.

\section{Results}

\section{The Influence of Clots on Thrombin Generation in PRP}

In recalcified PRP, there is a prolonged lag phase prior to the thrombin burst. Lag times preceding thrombin generation in a plasma milieu have been shown to be caused by the time required for a) factor $V$ and/or VIII activation and $b$ ) for the generation of a platelet procoagu- 


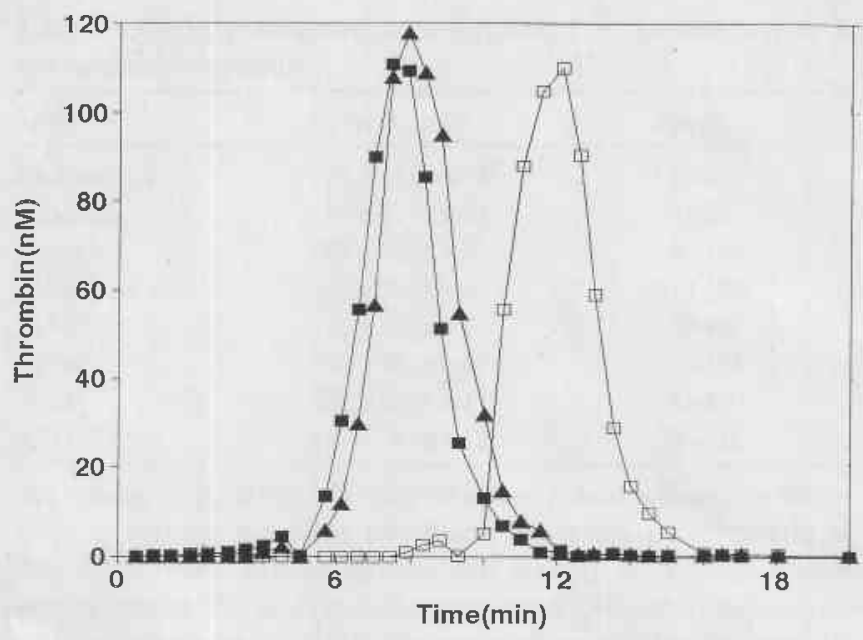

Fig. I The effect of fibrin clots on thrombin generation in PRP. Thrombin generation was triggered in PRP (platelet count $3^{*} 10^{8} / \mathrm{ml}$ ) by the addition of $\mathrm{Ca}^{2+}$ $(16.7 \mathrm{mM})$. The clots were added at $\mathrm{t}=90 \mathrm{~s}$. The amidolytic activity was determined in subsamples taken at $10 \mathrm{~s}$ intervals from which the thrombin activity was calculated (30). ( $\square$ ) Control without clots, ( $\mathbf{\square} 3$ Clots obtained by recalcifying plasma were added, ( $\boldsymbol{\Delta}$ ) 3 Clots obtained from purified fibrinogen by adding Agihal (Fibrin I clots) were added

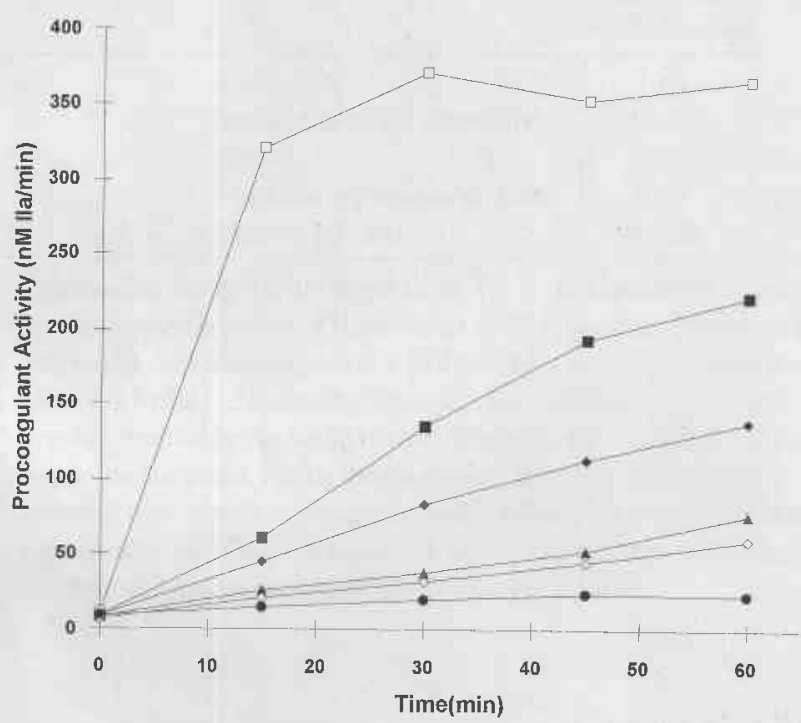

Fig. 2 Time course of platelet prothrombin converting activity in washed platelet suspensions. The stimulators were added to the platelet suspension (platelet count $0.5^{*} 10^{8} / \mathrm{ml}$ ) in the presence of $2 \mathrm{mM} \mathrm{Ca}^{2+}$. Prothrombin activation was measured at $1 \mu \mathrm{M}$ Prothrombin, $5 \mathrm{nM} \mathrm{Xa}, 3 \mathrm{nM}$ Va as described in detail in materials and methods. The various platelet activators shown are (ㄷ) $4 \mu \mathrm{M}$ A23187, ( 3 plasma clots, $(\diamond) 2$ plasma clots, $(\boldsymbol{\Delta}) 1$ plasma clot, $(\diamond) 28 \mathrm{nM}$ IIa. The control platelets $(-)$ where without any stimulator. Representative experiment of six so performed

lant surface under influence of traces of thrombin formed. We have shown previously that in PRP, under the conditions used here, the appearance of procoagulant phospholipids on/from the platelets is rate limiting for thrombin generation (30). The presence of plasma clots considerably shortens the lag time that precedes the thrombin burst in PRP (Fig. 1). Surprisingly, this effect is not critically dependent upon the presence of thrombin, clots generated by thrombin-like venom enzymes such as reptilase and Agihal, also shorten the lag phase in PRP.
Since Agihal and reptilase-clots (fibrin I clots) have been shown to be unable to promote factor V or VIII activation (18), this confirms the rate limiting role of platelet procoagulant phospholipids. This strongly suggests a direct effect of fibrin on the generation of platelet procoagulant activity. To test this hypothesis, we have studied the influence of fibrin clots on the generation of platelet procoagulant activity under conditions where no thrombin could be formed, i. e. in suspensions of washed platelets.

\section{The Effect of Plasma Clots on the Prothrombin-converting Activity of Washed Platelets}

Plasma clots were added to a washed platelet suspension and after different time intervals aliquots were drawn and transferred to assay mixtures containing prothrombin, factor $\mathrm{Xa}$, factor $\mathrm{Va}$ and $\mathrm{Ca}^{2+}$ ions, in which procoagulant lipid was the rate limiting component of prothrombinase. In this way the time course of generation of procoagulant activity (i. e. prothrombinase activity) in the platelet suspension was followed. The ability of clots to induce platelet procoagulant activity was compared with that of the established platelet activators, thrombin and the ionophore A23187 (Fig. 2). The incubation of platelets with clots results in an immediate appearance of procoagulant activity that linearly increases in time and that is proportional with the number of clots present in the platelet suspension. Platelets incubated with one plasma clot exhibit a 3-fold higher prothrombin-converting activity than control platelets. Activation of platelets with $30 \mathrm{nM}$ thrombin causes approximately the same effect as one clot. The stimulation by 3 plasma clots results in a linear increase that within one hour attains the level of $60 \%$ of the maximum procoagulant activitiy reached in platelet suspensions activated with the Ca-ionophore A23187. The initial rate of generation of procoagulant activity by the ionophore is, however, much higher than that obtained in the presence of clots.

The prothrombin-converting activities induced by plasma clots and other agonists (IIa, collagen, IIa plus collagen and A23187) are summarized in Table 1.

Under the conditions chosen in this experiment the capacity of the various activators to induce platelet procoagulant activity is in the order: A23187 $>3$ clots $>$ IIa plus collagen $>$ collagen $\geq 2$ clots $>1$ clot $\geq$ IIa $>$ no activator.

To check whether the generation of platelet procoagulant activity should be attributed to the clot itself or to a factor released from clots the control experiments presented in Table 2 were performed. Clots incubated with buffer in the absence of platelets do not induce any prothrombinase activity. This means that clots do not release a factor that on itself stimulates prothrombin activation. The supernatant of clots incubated in buffer was unable to generate prothrombin-converting activity in platelet suspensions. This excluded the possibility that some platelet-activating substance extrudes from the clots and shows that physical interaction between clots and platelets is a prerequisite for the generation of clot-induced procoagulant activity in platelet suspensions.

Another essential feature of clot-induced platelet procoagulant activity is the requirement for stirring during the incubation of platelets with the clot. A similar requirement has been reported for the generation of platelet prothrombin-converting activity by thrombin, collagen and $\mathrm{A} 23187(4,31)$.

In our earlier work (18) it has been attempted to quantify the amount of thrombin adsorbed to the clot by the technique of comparing the thrombin potential, the area under the thrombin time curve in the pre- 
Table 1 Platelet procoagulant activity provoked by different triggers in washed platelet suspensions

\begin{tabular}{lcc}
\hline Trigger & Level at $\mathrm{t}=60$ & Range \\
\hline Unstimulated & $23 \pm 5(\mathrm{n}=13)$ & $17-33$ \\
Thrombin & $66 \pm 21(\mathrm{n}=6)$ & $34-95$ \\
Collagen & $99 \pm 46(\mathrm{n}=3)$ & $62-165$ \\
Thromb + Coll & $138 \pm 20(\mathrm{n}=3)$ & $118-158$ \\
1 clot & $72 \pm 20(\mathrm{n}=6)$ & $47-101$ \\
2 clots & $91 \pm 38(\mathrm{n}=6)$ & $70-168$ \\
3 clots & $286 \pm 68(\mathrm{n}=13)$ & $84-450$ \\
A23187 & $414 \pm 70(\mathrm{n}=12)$ & $394-536$ \\
\hline
\end{tabular}

The amount of Ila formed (nM) after 60 min of platelet activation in the absence or presence of various stimulators. The results are represented as Avg. \pm SD (number of times the experiment is done). To express, the donor dependent scatter the range obtained is also given. Experimental conditions are the same as in legend of Fig. 2. The concentrations of stimulants were: IIa (30 $\mathrm{nM})$, Collagen $(10 \mu \mathrm{g} / \mathrm{ml})$, IIa/collagen $(1 \mathrm{nM} \mathrm{IIa} / 10 \mu \mathrm{g} / \mathrm{ml}$ collagen), A23187 (4 $\mu \mathrm{M})$. Fibrin II clots have been used.

Table 2 Requirements for the generation of prothrombin-converting activity in platelet-clot suspensions

\begin{tabular}{llc}
\hline Experiment & Reaction mixture & $\begin{array}{l}\text { Prothrombin- } \\
\text { converting activity } \\
\text { (nM IIa/min) }\end{array}$ \\
\hline 1 & Buffer & $5 \pm 1$ \\
2 & Supernatant of clot suspension & $6 \pm 2$ \\
3 & Platelets & $8 \pm 1$ \\
4 & Platelets + supernatant of 3 clots & $8 \pm 3$ \\
5 & Platelets +3 clots & $286 \pm 68$ \\
\hline
\end{tabular}

Experimental set up was the same as for Fig. 2. In experiments 1 and 3 the reaction mixture consisted of Hepes buffer ( $\mathrm{pH}$ 6.6. see materials and methods) and platelet suspension respectively. In experiment 2, the plasma clots were incubated in buffer in the absence of platelets. For experiment 4, the plasma clots were incubated in buffer for 30 minutes. The clots were taken out and platelet suspension was added. Finally in experiment 5 , the prothrombinase activity was measured when plasma clots were incubated with platelet suspension. In all the experiments $2 \mathrm{mM} \mathrm{Ca}^{2+}$ was added. The results are expressed as Average $\pm \mathrm{SD}$ ( $\mathrm{n}=5$ for first 4 experiments and $\mathrm{n}=13$ for experiment 5 ).

sence and absence of fibrinogen. The thrombin potential was found to be $31 \pm 3 \%($ mean \pm SEM, $n=10)$ lower in the presence than in the $a b-$ sence of fibrinogen with similar amounts of prothrombin being converted. This indicates that about $30 \%$ of all the thrombin formed is adsorbed on to fibrin. Indeed it was also seen that the peak level of free thrombin decreases from about $110 \mathrm{nM}$ to about $80 \mathrm{nM}$.

\section{Effect of Clots that do not Contain Thrombin}

The experiments reported above were performed with clots that are known to contain bound thrombin (i. e. uninhibited fibrin II clots). The experiments in Fig. 1 show that clots obtained by the action of snake venom enzymes on purified fibrinogen (fibrin I clots) are also able to generate platelet procoagulant activity. Figure 3 shows a time course of generation of prothrombin-converting activity in platelet suspensions in which fibrin I clots were used as platelet agonists. To ensure that venoms by themselves do not influence the reaction, Agihal and Reptilase were added to the platelet activation mixture in $1 / 50$ volume (as for obtaining the clots) and prothrombinase activity was measured (Inset graph, Fig. 3). With fibrin I clots, a modest but significant increase of the prothrombin-converting activity was seen, that was, however much lower than that of fibrin II clots. This is indicative for a role of both fibrin (I or II) and clot-bound thrombin in the generation of procoagulant activity in washed platelet suspensions.

The importance of clot-bound thrombin was further tested by determining the effect of plasma clots that were treated with an inhibitor of thrombin. To this end plasma clots (fibrin II clots) were incubated with $1 \mu \mathrm{M}$ of hirudin for about $2 \mathrm{~h}$, blotted dry and transferred to the platelet suspension without washing. In this way a small fraction of the hirudin is transferred to the platelet activation mixture, in order to ensure complete inhibition of thrombin bound to the clot. Since in our prothrombinase assay the platelet suspension is subsampled to a mixture with prothrombinase components, the hirudin that is carried over is diluted many times. We determined that the amount of hirudin carried over was less than $1 \mathrm{nM}$ in the final solution which will be too low to inhibit the thrombin formed in the assay mixture. However, to confirm this a control experiment was performed in which $30 \mathrm{nM}$ hirudin was added to the platelet mix containing three plasma clots. The time course of generation of platelet prothrombin converting activity was determined by drawing aliquots from the mixture and transferring them to the prothrombinase mix. By dilution just over $1 \mathrm{nM}$ hirudin reaches the final solution in this way. The amount of thrombin measured after $60 \mathrm{~min}$ of platelet activation was $326 \mathrm{nM}$ which is above the mean of 13 experiments without hirudin and within the mean \pm 1 SD range (Table 1).

Clot associated thrombin activity before and after hirudin treatment was determined by measuring the amidolytic activity on S2238. With three untreated fibrin II clots the thrombin measured after 15 min of in-

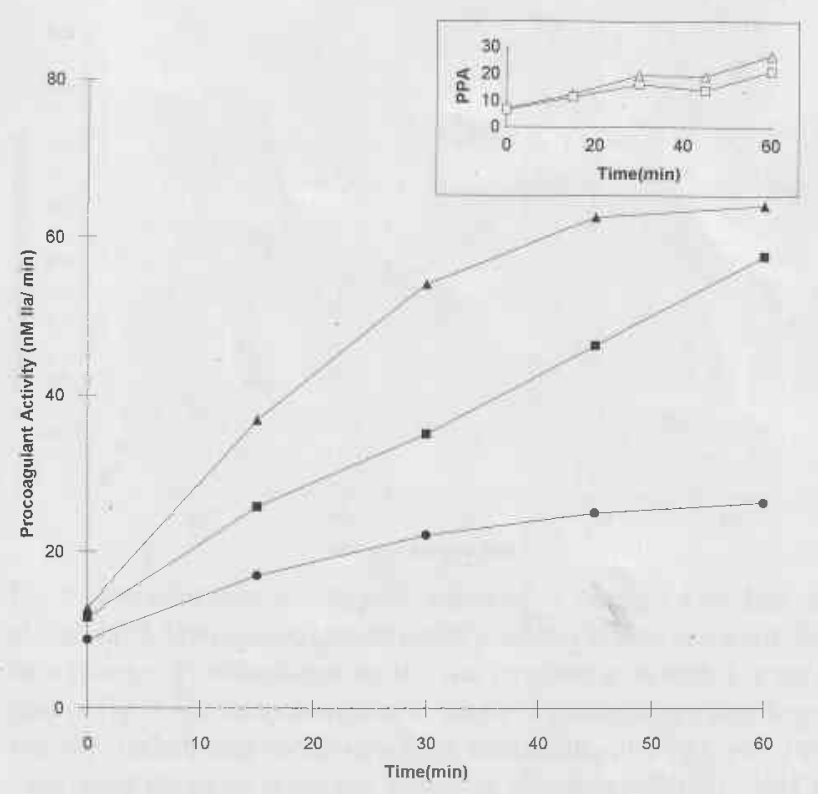

Fig. 3 Effect of addition of Fibrin I clots on platelet prothrombin converting activity in washed platelet suspensions. Experimental set up is the same as in legend of Fig. 2. The clots generated from purified fibrinogen by adding ( $\mathbf{\Delta})$ Agihal and ( $\mathbf{\square}$ Reptilase (Fibrin I clots not containing any thrombin) were used as platelet stimulators. The control platelets $($ ) were without any stimulator. 3 clots have been used. The graph represents average values for 6 donors. The inset graph represents the control experiment with Agihal $(\triangle)$ and Reptilase ( $\square$ ) added to the platelet activation mixture in $1 / 50$ volume 


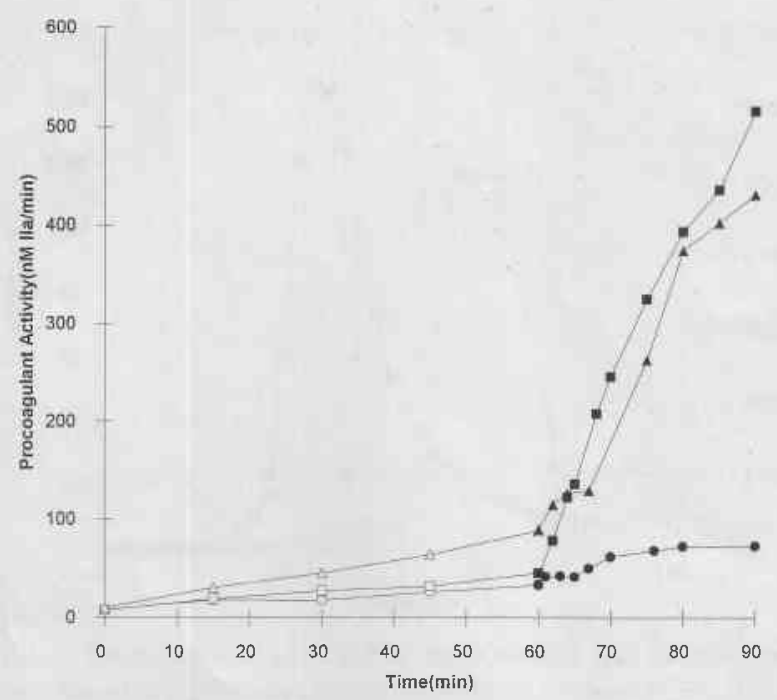

Fig. 4 Effect of addition of IIa to fibrin I clots and hirudin treated clots. Washed platelet suspension was activated by $(\square)$ Fibrin I clots and $(\Delta)$ plasma clots with inhibited IIa (treated with $1 \mu$ M Hirudin) for 60 minutes, after which $5 \mathrm{nM}$ IIa was added to the platelet activation mixture. The control platelets $(O)$ were without stimulator till 60 minutes and then $5 \mathrm{nM}$ IIa was added to them. The platelet procoagulant activity was measured as described in the legend of Fig. 2. The solid symbols represent the continuations of the same curves after thrombin addition

cubation was $14.8 \mathrm{nM}$ while after hirudin treatment $(1 \mu \mathrm{M})$ the value dropped to $1.28 \mathrm{nM}$. This residual activity is probably thrombin independent splitting of $\mathbf{S} 2238$ because the value observed for fibrin I clots produced without contact with thrombin was $1.15 \mathrm{nM}$.

Table 3 shows that thrombin-containing clots have a significantly higher activity than clots that do not contain thrombin but that the latter anyhow also exhibit activity.

\section{The Effect of Thrombin on the Prothrombin-converting Activity of Platelet-clot Suspensions}

Washed platelets were incubated for $60 \mathrm{~min}$ in the presence of clots that did not contain active thrombin (fibrin I clots or hirudin-treated plasma clots) prior to the addition of $5 \mathrm{nM}$ thrombin. Figure 4 shows that the addition of thrombin to platelet suspensions that contain clots causes the platelet procoagulant activity to rise steeply to levels that

Table 3 Comparison of activities evoked by various clots in washed platelet suspensions

\begin{tabular}{lc}
\hline Agonist & $\begin{array}{c}\text { \% Procoagulant activity } \\
\text { (after 60 min of platelet activation) }\end{array}$ \\
\hline Plasma clots & $100 \pm 9.8$ \\
Fibrinogen + IIa $(30 \mathrm{nM}$ ) clots & $98 \pm 10.2$ \\
Plasma clots treated Hirudin $(1 \mu \mathrm{M})$ & $26 \pm 4.6$ \\
Fibrin I clots & $21 \pm 4.8$ \\
None & $8 \pm 1.1$ \\
\hline
\end{tabular}

Experimental set up is the same as for Fig. 2. The various clots were obtained as described under methods. For the purpose of comparison the prothrombinase activity induced by plasma clots has been taken as $100 \%$ value. The data obtained for 9 donors is expressed as Average \pm SEM. even exceed those obtained with the Ca-ionophore A23187. Such a rise does not occur when thrombin is added to control platelets incubated without clots. In these experiments the levels of prothrombin-converting activitiy are much higher than those obtained with untreated plasma clots. This indicates that the synergistic effect of free thrombin in the generation of fibrin-induced platelet procoagulant activity is much more pronounced than that of clot-bound thrombin.

\section{Leakage of Lactate Dehydrogenase}

Platelet procoagulant activity can result from a transbilayer transport of phosphatidylserine to the outside of the intact membrane (flip-flop), by the shedding of microparticles or by disruption of the cell membrane. As a measure of membrane disruption we used the release of cytoplasmic lactate dehydrogenase. To estimate the contribution of membrane damage to the generation of procoagulant activity we plotted the latter as a function of the release of LDH (Fig. 5). It is seen that the combination of thrombin with clots (of any type) causes procoagulant activity that is accompanied by substantial release of $\mathrm{LDH}$, as is, a fortiori, the activity produced by sonication. Thrombin plus collagen, or the Ca-ionophore cause a release of LDH that, for the same amount of procoagulant activity, is only $20 \%$ of maximal. So the platelet procoagulant activity induced by clots in washed platelets is lysis associated.

This imposed LDH measurements in PRP during thrombin generation. The LDH level measured in PPP was $102 \mathrm{U} / \mathrm{l}$, in sonicated PRP the level was $594 \mathrm{U} / \mathrm{ml}$. However in PRP, not significant rise in LDH was obtained (Fig. 6). Knowing the experimental variation of the individual measurements, this means that less than $1 \%$ of the platelets had shed its LDH during the clotting of PRP.

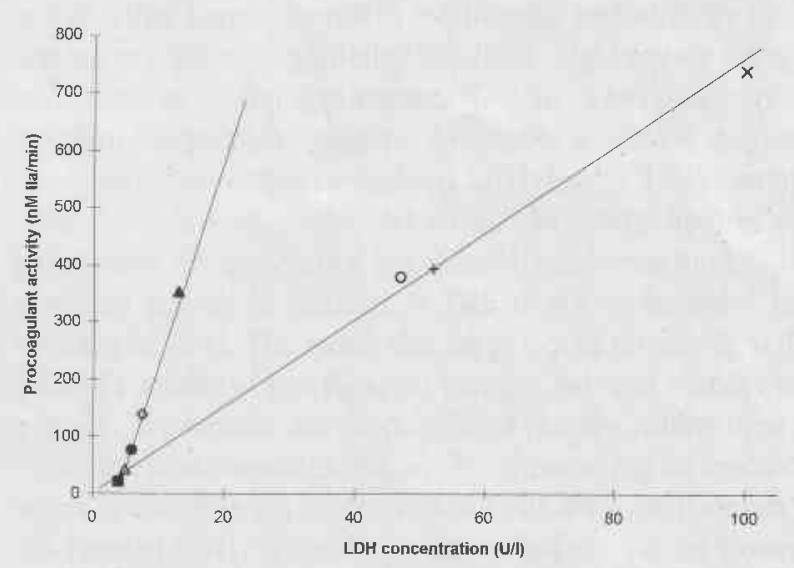

Fig. 5 Prothrombinase activity with corresponding Platelet Lactate Dehydrogenase (LDH, U/1) obtained after 60 min of platelet activation in washed platelet suspension. Prothrombinase activity was measured as described in the legend of Fig. 2. For the measurement of release of platelet lactate dehydrogenase, $200 \mu \mathrm{l}$ of activated platelet suspension was centrifuged at $9000 \mathrm{~g}$ for $3 \mathrm{~min}$. Supernatant was added to a cuvette containing Phosphate buffer $(51.7 \mathrm{mM}, \mathrm{pH}$ 7.5), NADH $(0.19 \mathrm{mM})$, Pyruvate $(0.6 \mathrm{mM})$. The activity of LDH was calculated from the absorbency change at $334 \mathrm{~nm}$. The total LDH content of platelet suspension was determined in a sonicated sample $(x)$. The other points represent the values obtained when the agonist were: $(\Delta)$ Fibrin I clots; ( + ) Fibrin I clots with $5 \mathrm{nM}$ thrombin added to the platelet activation mixture after 60 min of platelet activation; (O) Plasma clots; $(0)$ Plasma clots treated with hirudin; $(\diamond)$ Thrombin/collagen ( $1 \mathrm{nM}$ thrombin/10 $\mu \mathrm{g} / \mathrm{ml}$ collagen); ( $\mathbf{\Delta})$ $\mathrm{Ca}^{2+}$ ionophore and ( $)$ none 


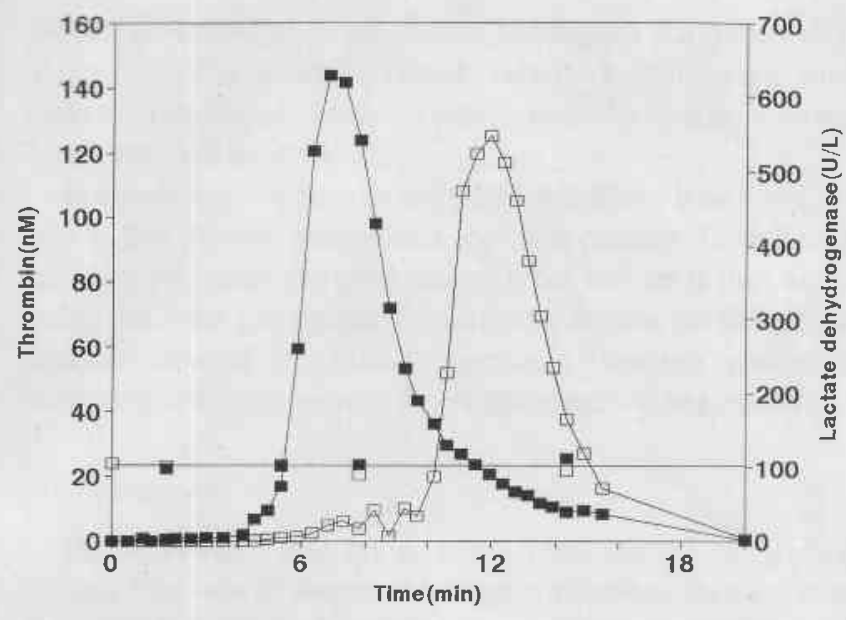

Fig. 6 Measurement of LDH in PRP simultaneously with thrombin generation. Thrombin generation was triggered in $\mathrm{PRP}$ by addition of $\mathrm{Ca}^{2+}(16.7 \mathrm{mM})$.

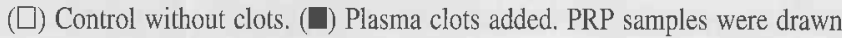
from both the parallel experiments at various time intervals and analyzed for the release of LDH (shown on left $Y$ axis) as described in legends of Fig. 5. The horizontal line represents the base LDH obtained in PPP i. e. $102 \mathrm{U} / 1$ and the points about it give the LDH values measured for the two series in the same symbols. The LDH value obtained for sonicated PRP was $594 \mathrm{U} / \mathrm{l}$

Table 4 Generation of platelet procoagulant activity in platelet rich plasma on addition of clots

\begin{tabular}{lc}
\hline Reaction Mixture & $\begin{array}{c}\text { Prothrombin Converting Activity } \\
\text { (nM IIa/min) }\end{array}$ \\
\hline PRP & $43 \pm 9$ \\
PRP + 3 plasma clots & $151 \pm 34$ \\
PRP + 3 clots from purified fibrinogen & $72 \pm 15$ \\
PPP & $21 \pm 6$ \\
\hline
\end{tabular}

For the measurement of platelet procoagulant activity, $100 \mu \mathrm{l}$ of PRP $\left(1 * 10^{8} / \mathrm{ml}\right)$ was diluted 1:6.7 in Tris buffer A (see materials) and incubated with or without clots for 5 minutes. $50 \mu \mathrm{l}$ subsample was transferred to $100 \mu \mathrm{l}$ of prothrombinase mixture containing $\mathrm{Xa}(0.45 \mathrm{nM}), \mathrm{Va}(10.5 \mathrm{nM})$, Prothrombin $(3 \mu \mathrm{M}), \mathrm{Ca}^{2+}(12 \mathrm{mM})$. At $4 \mathrm{~min}$, the reaction was stopped by taking $10 \mu \mathrm{l}$ subsample to cuvette with $465 \mu \mathrm{l}$ Tris buffer B (with EDTA). The amount of thrombin formed was calculated from the absorbance change at $405 \mathrm{~nm}$ after adding $4 \mathrm{mM} \mathrm{S2238}$. The results are expressed as Average \pm SD for 5 experiments.

\section{Platelet Procoagulant Activity Generated in PRP in the Presence of Clots}

In order to confirm the action of clots on the disclosure of procoagulant phospholipids by clots, both fibrin I and fibrin II clots were added to PRP and the generation of platelet procoagulant activity was followed in subsamples that were transferred to a prothrombinase mixture devoid of phospholipids, as used for washed platelets. Table 4 lists the values obtained after 4 min of activation. Measurements simultaneously carried for PPP incubated with clots and PRP without clots served as controls.

\section{Discussion}

We previously reported that thrombin bound to fibrin is capable to activate factors V and VIII (18). In the course of these experiments it appeared that fibrin clots, even if they did not contain thrombin, foster thrombin generation in platelet rich plasma (PRP). In this article was further investigate the mechanism behind this phenomenon.

Platelets can assist in thrombin generation by exposing procoagulant phospholipid and by releasing factor $V$. Under our experimental conditions, i. e. in 2:3 diluted normal PRP, factor $V$ is present in excess and procoagulant lipids are rate limiting (30). Therefore the release of factor $\mathrm{V}$ does not contribute significantly to the thrombin generating capacity of PRP but the availability of procoagulant phospholipid from platelets does. So, if fibrin clots enhance thrombin generation in PRP, these clots must induce the exposure of such phospholipids.

Platelet procoagulant phospholipid activity, also called platelet factor 3 (PF3), is dependent upon the exposure of negatively charged phospholipids, chiefly phosphatidylserine (PS). In the resting platelet, PS is almost exclusively located in the cytoplasmic layer of the cell membrane. Upon activation by thrombin or collagen, and especially if both activators are present, PS is transferred from the inner to the outer monolayer of the intact membrane (3). In this process platelets also shed procoagulant phospholipid particles $(32,33)$. PS also gets exposed when the platelet membrane is disrupted by methods such as freeze thawing or sonication. Such extreme situations however do not occur in vivo and their biological significance seems limited.

Our results show that fibrin clots of any type provoke platelet procoagulant activity in PRP as well as in washed platelet suspensions. Notably non cross-linked fibrin I clots, obtained with snake venom enzymes that only release fibrinopeptide A, still exhibit activity. In isolated platelets the presence of thrombin is necessary for a maximal effect (Table 3). This may be thrombin already adsorbed to the clot. In plasma, where explosive thrombin generation necessarily follows the appearance of platelet procoagulant activity, it is hard to distinguish between the effect of fibrin alone and that of fibrin plus thrombin.

Contrary to what could be expected from its effect on the isolated platelets (3), collagen has been reported not to enhance thrombin generation in PRP (30). The obvious difference between the two situations is that in PRP fibrin is formed by the thrombin generated. We therefore wanted to explore the possibility that fibrin might replace collagen as an inductor of the flip-flop reaction. However, when isolated platelets are stirrred with clots, especially if thrombin is present too, they disrupt, as can be judged from their shedding LDH (Fig. 5). This experimental setup therefore is not suitable for the demonstration of flip-flop, and the experiments are inconclusive. In contrast, the induction by clots of procoagulant activity in platelets in PRP is not accompanied by the shedding of LDH. This means that the procoagulant activity is due to PS at the outside of non-disrupted platelets and/or of shedded microparticles. We suppose that the isolation of platelets renders them more vulnerable than platelets in PRP are. We are searching for conditions in which isolated platelets can be incubated with fibrin and thrombin without shedding LDH but thus far we did not find any. For the moment we have no data that make us revise our original hypothesis that fibrin in clotting plasma can play a similar role as collagen does in suspensions of isolated platelets.

Our observations broach the question of in how far platelet disruption may be an integral part of the physiological haemostatic reaction. It is not uncommon for cell death to contribute to physiological functions (cf. holocrine secretion) (34) and disrupted platelets are a common phenomenon in EM pictures of the haemostatic plug (35).

In Table 1 we observe a large variation in platelet procoagulant activity. This is only partly due to random experimental error. In fact the experimental variation when calculated from experiments carried out on the same platelet suspension under identical conditions was less than $8 \%$. The remainder of the variation must be ascribed to variation of 
the platelet reactivity between donors. This suggest that platelet excitability may vary considerably between subjects. It would be interesting to do epidemiological studies on platelet reactivity in relation to age, illness and cardiovascular risk.

In conclusion: We have demonstrated that fibrin, both type I and type II, does provoke procoagulant activity in platelets. Thrombin significantly potentiates this phenomenon. When they are in their natural milieu this is not accompanied by platelet breakdown, but isolated platelets are damaged during these experiments. There is a considerable variation in reactivity between donors that remains to be explored.

\section{Acknowledgements}

The authors wish to thank Drs. Jan Rosing, Guido Tans and Hu Kai as well as Stella Thomassen for their extensive support and critical discussion of the manuscript. Part of this work was carried out under a program grant from NWO (900-526-192).

\section{References}

1. Hemker HC. Thrombin Generation, an Essential Step in Haemostasis and Thrombosis. In: Haemostasis and Thrombosis. 3rd edt. Bloom AL, Forbes CD, Thomas DP, Tuddenham EGD (edts). London: Churchill Livingstone 1993. ISBN 0-443-04521b, pp 477-90.

2. Walsh PN. Different requirements for intrinsic factor Xa forming activity and platelet factor 3 activity and their relationship to platelet aggregation and secretion. Br J Haematol 1978; 40: 311 .

3. Bevers EM, Comfurius P, van Rijn JLML, Hemker HC, Zwaal RFA. Generation of Prothrombin converting activity and the exposure of phosphatidylserine at the outer surface of platelets. Eur J Biochem 1982; 122: 429-36.

4. Rosing J, van Rijn JLML, Bevers EM, van Dieijen G, Comfurius P, Zwaal RFA. The role of activated human platelets in prothrombin and factor $\mathrm{X}$ activation. Blood 1985; 65: 319-32.

5. Miletich JP, Jackson CM, Majerus PW. Properties of the factor Xa binding site on platelets. J Biol Chem 1978; 253: 6908-16.

6. Kane WH, Lindhout MJ, Jackson CM, Majerus PW. Factor Va-dependent binding of factor Xa to human platelets. J Biol Chem 1980; 255: 1170-4.

7. Chasney CM, Pifer D, Colman RW. Subcellular localization and secretion of factor V from human platelets. Proc Natl Acad Sci USA 1981; 78: 5180-4.

8. Liu CY, Nossel HL, Kaplan KL. The binding of thrombin by fibrin. J Biol Chem 1979; 254: 10421-5.

9. Kaminski M, Mcdonagh J. Inhibited thrombins, interactions with fibrinogen and fibrin. Biochem J 1987; 242: 881-7.

10. Wilner GD, Danitz MP, Mudd S, Hsieh K, Fenton JW. Selective immobalization of thrombin by surface bound fibrin. J Lab Clin Med 1981; 97 : 403-11.

11. Hogg PJ, Jackson CM. Fibrin monomer protects thrombin from inactivation by heparin-antithrombin III: Implications for heparin efficacy. Proc Natl Acad Sci USA 1989; 86: 3619-23.

12. Weitz JI, Hudoba M, Massel D, Maraganore J, Hirsh J. Clot bound thrombin is protected from inhibition by heparin-antithrombin III but is susceptible to inactivation by antithrombin III independent inhibitors. J Clin Invest 1990; 86: 385-91

13. Francis WC, Markham ER, Barlow HG, Florack MT, Dobrzynski MD, Marder JV. Thrombin activity of fibrin thrombi and soluble plasmic derivatives. J Lab Clin Med 1983; 102: 220-30.
14. Prins MH, Weitz JI. Heparin inhibits the amplification of coagulation mediated by clot-bound thrombin. Thromb Haemost 1991; 65: 759 (abstract 319).

15. Bendayan P, Boccalon H, Dupouy D, Boneu B. Dermatan sulfate is a more potent inhibitor of clot-bound thrombin than unfractionated and low molecular weight heparins. Thromb Haemost 1994; 71: 576-80.

16. Buchanan A. Original communications on the coagulation of the blood and other fibriniferous liquids. London: Med Gaz 1845.

17. Béguin S, Kessels H, Hemker HC. Feedback reactions in blood coagulation are mediated by fibrin bound thrombin which is not inhibited by heparin. Thromb Haemost 1993; 69: 811, Abstract 962.

18. Kumar R, Béguin S, Hemker HC. The influence of fibrinogen and fibrin on thrombin generation-evidence for feedback activation of the clotting system by clot bound thrombin. Thromb Haemost 1994; 72 (5): 713-21.

19. Keiffer N, Phillips DR. Platelet membrane glycoproteins: Functions in cellular interactions. Annu Rev Cell Biol 1990; 6: 329-57.

20. Bevers E, Comfurius P, Zwaal RFA. Changes in membrane phospholipid distribution during platelet activation. Biochim et Biophysica Acta 1983; 736: $57-66$

21. Discipio RG, Hermodson MA, Yates SG, Davie EW. A comparison of human prothrombin, factor IXa (Christmas factor), factor X (Stuart factor) and protein S. Biochemistry 1977; 16: 698-706.

22. Rosing J, Tans G, Govers-Riemslag JWP, Zwaal RFA, Hemker HC. The role of phospholipids and factor $\mathrm{Va}$ in the prothrombinase complex. J Biol Chem 1980; 255: 274-83.

23. Chase T Jr, Shaw E Comparison of the esterase activities of trypsin, plas$\min$ and thrombin on guanidinobenzoate esters. Titration of the enzymes. Biochemistry 1969; 8: 2212-24.

24. Fujikawa K, Legaz ME, Davie EW. Bovine factor $X_{1}$ (Stuart factor). Mechanism of activation by protein from Russell's viper venom. Biochemistry 1972; 11: 4892-9.

25. Smith RL. Titration of activated bovine factor X. J Biol Chem 1973; 248: 2418-23.

26. Dählback B. Human coagulation factor $V$ purification and thrombin-catalyzed activation. J Clin Invest 1980; 66: 583-91.

27. Suzuki K, Dählback B, Stenflo J. Thrombin-catalyzed activation of human coagulation factor V. J Biol Chem 1982; 257: 6556-64.

28. Tans G, Rosing J, Thomassen MCLGD, Heeb MJ, Zwaal RFA, Griffin JH. Comparison of anticoagulant and procoagulant activities of stimulated platelets and platelet derived microparticles. Blood 1991; 77 (12): 2641-8.

29. Lindhout T, Govers-Riemslag JWP, van de Waart P, Hemker HC, Rosing J. Factor Va-factor Xa interactions. Effect of phospholipid vesicles of varying composition. Biochemistry 1982; 21: 5494-502.

30. Béguin S, Lindhout T, Hemker HC. The effect of trace amounts of Tissue Factor on Thrombin Generation in Platelet Rich Plasma, its inhibition by Heparin. Thromb Haemost 1989; 61 (1): 25-9.

31. van Rijn JLML, Rosing J, van Dieijen G. Activity of human blood platelets in prothrombin and in factor $\mathrm{X}$ activation induced by lonophore A23187. Eur J Biochem 1983; 133: 1-10.

32. Schroit AJ, Zwaal RFA. Transbilayer movement of phospholipids in ted cell and platelet membrane. Biochim Biophys Acta 1991; 1071 (3): 313-29.

33. Sandberg H, Andersson LO, Hoglund S. Isolation and characterization of lipid-protein particles containing platelet factor 3 released from human platelets. Biochem J 1982; 203 (1): 303-11.

34. Agache P, Blanc D. Current status in sebum knowledge. Int J Dermatol 1982; 21 (6): 304-15.

35. Wester J, Sixma JJ, Geuze JJ, van der Veen J. Morphology of the hemostatic plug in human skin wounds. Transformation of the plug. Labaratory Investigation 1979; 41: 182-92.

Received February 13, 1995 Accepted after resubmission May 23, 1995 